\title{
Single intravitreal ranibizumab for myopic choroidal neovascularization
}

This article was published in the following Dove Press journal:

Clinical Ophthalmology

3 August 201I

Number of times this article has been viewed

\section{Saidin Nor-Masniwati Ismail Shatriah \\ Embong Zunaina}

Department of Ophthalmology, Universiti Sains Malaysia, Kelantan, Malaysia
Correspondence: Embong Zunaina Department of Ophthalmology, School of Medical Sciences, Universiti Sains

Kelantan, Malaysia

Tel +6097676362

Fax +6097653370

Email zunaina@kb.usm.my Malaysia, I6I50 Kubang Kerian,

Abstract: We report a case of myopic choroidal neovascularization that showed improvement after a single injection of ranibizumab. A 45-year-old Chinese man with high myopia presented with sudden onset painless central scotoma of his right eye of 2 weeks' duration. There was no history of trauma. His right eye vision on presentation was $6 / 30$ which showed no improvement with pinhole. The right fundus showed myopic maculopathy at the posterior pole with subretinal hemorrhage at the inferotemporal fovea. The optic disc was tilted with inferotemporal peripapillary atrophy. There was a myopic maculopathy appearance in the macula of the left eye. Fundus fluorescein angiography revealed choroidal neovascularization at the fovea of the right eye. A diagnosis of right eye choroidal neovascularization secondary to myopic maculopathy was made. A single intravitreal injection of ranibizumab $0.05 \mathrm{~mL}$ was given. Ten weeks following intravitreal injection, vision had improved to $6 / 7.5$, and repeated fundus fluorescein angiography showed absence of choroidal neovascularization. Follow-up at 6 months showed visual acuity had normalized to $6 / 6$ with glasses, which was maintained up to 12 months following treatment. The right fundus showed no further subretinal hemorrhage with no new lesions.

Keywords: myopia, choroidal neovascularization, antivascular endothelial growth factor

\section{Introduction}

Choroidal neovascularization (CNV) is a common cause of vision loss in pathological myopia. ${ }^{1}$ The pathogenesis of CNV in pathological myopia is still unclear but is postulated to result from axial elongation of the globe causing distension of the posterior segment with greater ocular volume than in the normal eye. This results in stretching of the macula within the staphyloma and induces intraretinal retinochisis. Later on, the formation of lacquer cracks leads to $\mathrm{CNV}{ }^{1}$

The most appropriate treatment for myopic CNV has not yet been established and the choices are limited. ${ }^{2}$ Antivascular endothelial growth factor seems to offer a new modality for management of pathological myopia. We report a case of myopic CNV that showed improvement after a single injection of ranibizumab.

\section{Case report}

A 45-year-old Chinese man, who was a known case of high myopia with a spherical equivalent refractive error of -5.0 diopter (D), presented with sudden onset painless reduced vision of his right eye of 2 weeks' duration. He described it as a central scotoma. There was no metamorphopsia, and there was no relationship with headache, jaw claudication, or double vision. He had undergone bilateral cataract surgery 10 years before presentation, and had a good visual outcome postoperatively with glasses. The cataract operation was uneventful and there was no history of eye trauma. 
His right vision on presentation was 6/30 which was not improved with pinhole and 6/6 for the left eye. The anterior segments revealed a clear cornea bilaterally, and a deep anterior chamber with intraocular pressures of $14 \mathrm{mmHg}$ (right eye) and $16 \mathrm{mmHg}$ (left eye). There were no vitreous cells and no vitreous hemorrhage. The right fundus showed chorioretinal atrophy at the posterior pole, with a subretinal hemorrhage at the inferotemporal fovea (Figure 1). The optic disc was tilted, with inferotemporal peripapillary atrophy. The macula of the left eye showed myopic maculopathy with a chorioretinal atrophy appearance and without subretinal hemorrhage. Fundus fluorescein angiography of the right eye revealed a hyperfluorescent area at the fovea which was increasing in intensity and size (Figure 2). A diagnosis of CNV secondary to myopia of the right eye was made. Due to logistical problems, optical coherence tomography was not performed in this patient.

An intravitreal injection of ranibizumab $0.05 \mathrm{~mL}$ (Lucentis ${ }^{\circledR}$, Novartis, Basel, Switzerland) was given to the right eye. The patient was treated with moxifloxacin ophthalmic solution $0.5 \%$ (Alcon $^{\circledR}$, Alcon Laboratories Inc, Fort Worth, TX) at 4-hourly intervals for 3 days following the procedure. After 1 week of intravitreal ranibizumab injections, visual acuity improved to $6 / 15$ with pinhole. The intraocular pressure was normal, and no complications, such as intraocular infection, retinal tear, or vitreous hemorrhage was seen. The fundus showed that the subretinal hemorrhage had become less dense and was reducing in size (Figure 3). At 10-week follow-up, visual acuity improved to 6/7.5 with glasses, and repeat fundus fluorescein angiography showed the absence of CNV (Figure 4). Follow-up at 6 months showed that visual acuity had normalized to $6 / 6$ with glasses, which was maintained up to 12 months after treatment. The right fundus showed no subretinal hemorrhage with no new lesions.

\section{Discussion}

By definition, pathological myopia is also known as high, degenerative, or malignant myopia which is characterized as

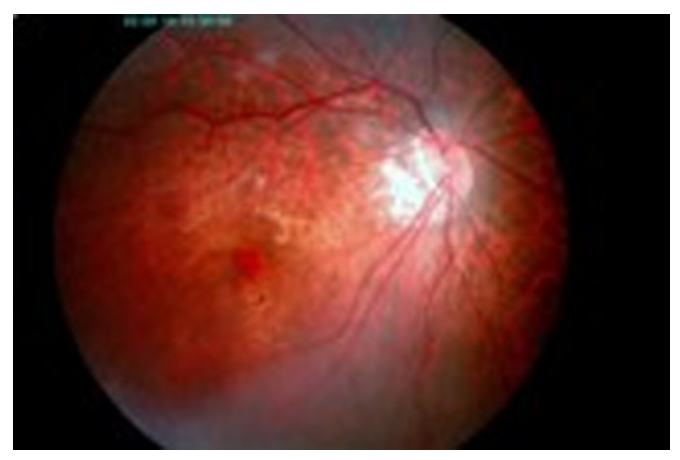

Figure I The right fundus showed subretinal hemorrhage at inferotemporal fovea and tilted disc with inferotemporal peripapillary atrophy.
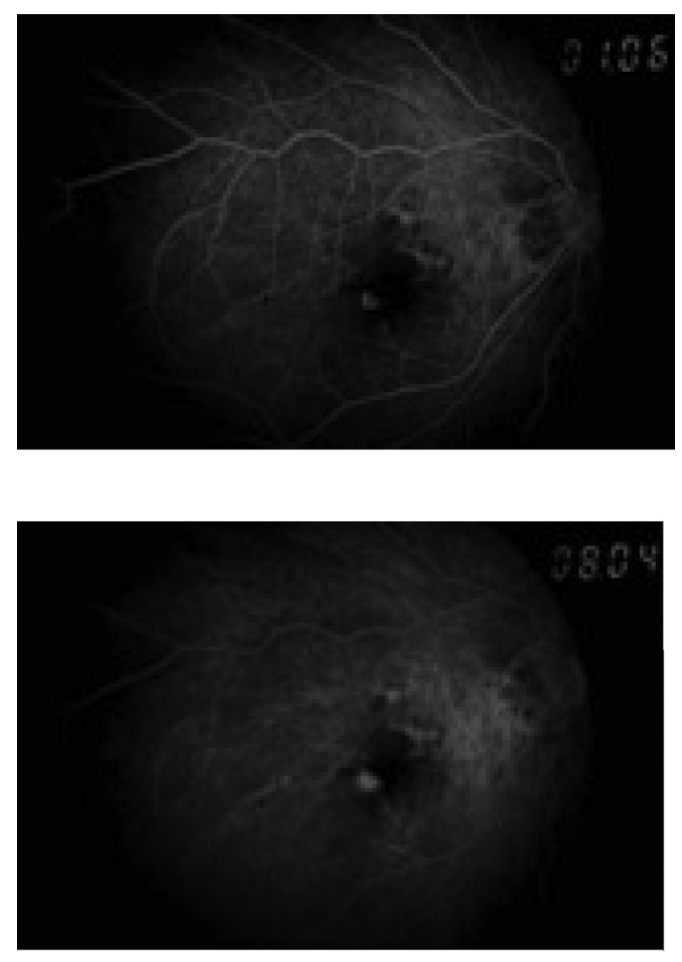

Figure 2 The FFA of the right eye showed the presence of choroidal neovascularisation with the evidence of hyperfluoresence area at the fovea which increased in intensity and size throughout the phase.

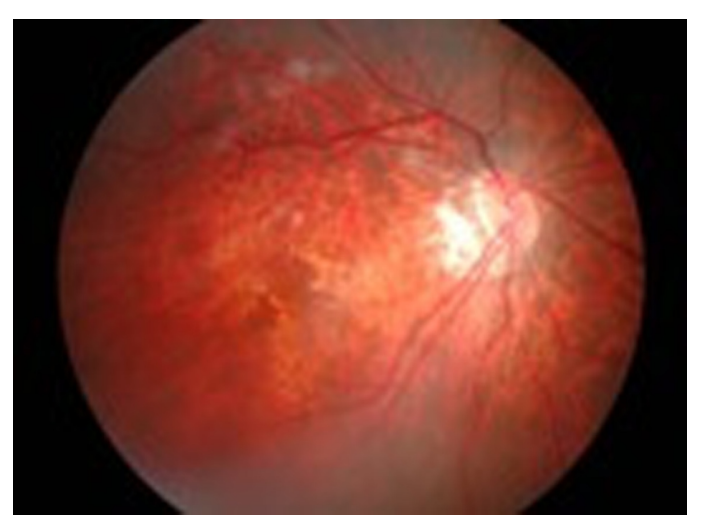

Figure 3 Right fundus showed the subretinal hemorrhage became less dense and reducing in size at one week post intravitreal ranibizumab.

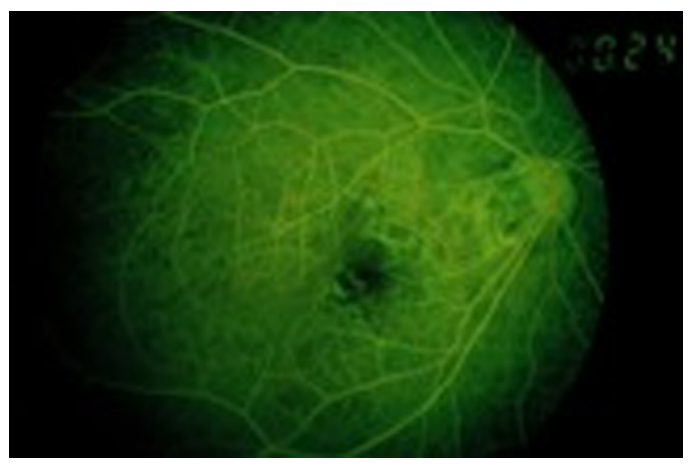

Figure 4 Repeated FFA showed no more features of choroidal neovascularisation in right eye. 
excessive elongation of axial length from 25.5 to $26.5 \mathrm{~mm}$ and refractive errors of at least -5.0 or -7.5 D. ${ }^{2}$

The risk factors for development of pathological myopia depend on ethnicity and genetics, whereas increased intraocular pressure and retinal degeneration, such as lacquer cracks and patchy atrophy, are risk factors for developing CNV secondary to pathological myopia. The prevalence is higher in Asian populations, whereas six autosomal dominant loci and one X-linked recessive locus have been reported for pathological myopia. ${ }^{2}$ In this case, the patient's spherical equivalent refractive error was $-5.0 \mathrm{D}$ which is one of the risk factors for developing CNV secondary to myopia.

Several treatments have been proposed to treat myopic $\mathrm{CNV}$, including laser photocoagulation, ${ }^{2,3}$ surgical removal of $\mathrm{CNV}^{4,5}$ macular translocation, ${ }^{4,6}$ and photodynamic therapy with and without intravitreal triamcinolone acetonide, ${ }^{1,7,8}$ but the most appropriate treatment has not yet been established.

Laser photocoagulation seemed to cause more harm than no treatment in an early study, but subsequent studies showed more efficacy in preventing irreversible visual loss. Laser photocoagulation should be considered in extrafoveal cases compared with juxtafoveal due to long-term expansion of laser scar causing decrease in visual acuity. ${ }^{2}$

Photodynamic therapy with verteporfin is the other treatment option for subfoveal CNV in pathological myopia. In one study, a group treated with photodynamic therapy had more stable visual acuity compared with a placebo group. ${ }^{1}$

There are two main surgical procedures for CNV pathological myopia, ie, macular translocation and surgical removal. Hamelin et al compared these surgical procedures, but no significant difference was found in postoperative best corrected visual acuity. However, recurrence of CNV was more common after surgical removal and the incidence of retinal detachment was similar in both groups. ${ }^{4}$

Recent reports have suggested that antivascular endothelial growth factor could be a new modality for the management of pathological myopia. ${ }^{9-13}$ Ranibizumab has been found to be effective in the treatment of exudative age-related macular degeneration. ${ }^{14} \mathrm{CNV}$ due to pathological myopia is not associated with significant retinal edema, so the retinal barriers might be less disturbed in comparison with age-related

Table I Reported studies and case report of intravitreal ranibizumab for myopic choroidal neovascularization

\begin{tabular}{|c|c|c|c|c|}
\hline Reference & Study & Injections (n) & Outcome of visual acuity & Outcome of OCT \\
\hline $\begin{array}{l}\text { Calvo-Gonzalez } \\
\text { et } \mathrm{al}^{15}\end{array}$ & $\begin{array}{l}\text { Prospective interventional } \\
\text { case series, } 67 \text { eyes, follow-up } \\
\text { mean } 15.9 \text { months }\end{array}$ & 4.2 (mean) & $\begin{array}{l}\text { 79.1\% BCVA improved } \\
40.3 \% \text { gained more than } 15 \text { letters }\end{array}$ & Mean CMT reduction: $93.6 \mu \mathrm{m}$ \\
\hline $\begin{array}{l}\text { Silva } \\
\text { et } \text { al }^{16}\end{array}$ & $\begin{array}{l}\text { Prospective, multicenter, } \\
\text { consecutive, nonrandomized, } \\
\text { interventional case series, } \\
34 \text { eyes, follow-up } \geq 12 \text { months }\end{array}$ & 3.6 (mean) & $\begin{array}{l}\text { Mean VA improved } 8 \text { letters } \\
(P<0.00 \mathrm{I}), 24 \% \text { improved } \\
\geq 3 \text { lines }\end{array}$ & $\begin{array}{l}\text { CMT decreased from baseline } \\
(P<0.0 \mathrm{I})\end{array}$ \\
\hline $\begin{array}{l}\text { Konstantinidis } \\
\text { et al" }\end{array}$ & $\begin{array}{l}\text { Prospective, consecutive, } \\
\text { interventional study, I } 4 \text { eyes, } \\
\text { mean follow-up } 8.4 \text { months }\end{array}$ & 2.36 (mean) & $\begin{array}{l}\text { Mean logMAR BCVA improved } \\
\text { from } 0.7 \text { I to } 0.32 \text {, VA improved } \\
\text { by a mean of } 3.86 \text { lines, } \\
64 \% \text { gained } \geq 3 \text { lines }\end{array}$ & $\begin{array}{l}\text { Mean CMT decreased from } \\
304 \mu \mathrm{m} \text { to I } 53 \mu \mathrm{m}(P=0.0 \mathrm{I} 5) \text {, } \\
\text { mean CMT reduction } 170 \mu \mathrm{m}\end{array}$ \\
\hline $\begin{array}{l}\text { Mones } \\
\text { et } \mathrm{al}^{17}\end{array}$ & $\begin{array}{l}\text { Prospective, consecutive, } \\
\text { nonrandomized, interventional case } \\
\text { series, } 23 \text { eyes, follow-up } 12 \text { months }\end{array}$ & $\mathrm{I} .52$ (mean) & $\begin{array}{l}\text { Mean VA improved by } 9.53 \text { letters } \\
(P<0.05), 34.7 \% \text { increased } 3 \\
\text { or more lines }\end{array}$ & Not stated \\
\hline $\begin{array}{l}\text { Kumaran } \\
\text { et al }{ }^{18}\end{array}$ & $\begin{array}{l}\text { Case report, I eye, follow-up } \\
16 \text { months }\end{array}$ & 1 & Improved from $6 / 24$ to $6 / 9$ & $\begin{array}{l}\text { Complete resolution of } \\
\text { subretinal fluid }\end{array}$ \\
\hline $\begin{array}{l}\text { Lai } \\
\text { et } \mathrm{al}^{19}\end{array}$ & $\begin{array}{l}\text { Consecutive patients, } 16 \text { eyes, } \\
\text { follow-up } 12 \text { months }\end{array}$ & $\begin{array}{l}\text { I injection } \\
\text { (I5 eyes); } \\
2 \text { injections } \\
\text { ( I eye) }\end{array}$ & $\begin{array}{l}\text { Mean logMAR BCVA improved } \\
\text { from } 0.58(20 / 76) \text { to } 0.28(20 / 37) \\
(P<0.001) ; \text { mean improvement } \\
3.0 \text { lines; } 75 \% \text { improved } \geq 2 \text { lines }\end{array}$ & $\begin{array}{l}\text { Reduction mean central } \\
\text { foveal thickness }(P<0.001)\end{array}$ \\
\hline $\begin{array}{l}\text { Torron } \\
\text { et } \mathrm{al}^{20}\end{array}$ & $\begin{array}{l}\text { Retrospective, noncomparative } \\
\text { study, } 18 \text { eyes, follow-up } 6 \text { months }\end{array}$ & Not stated & $\begin{array}{l}\text { Mean BCVA improved from } 0.25 \\
\text { to } 0.46(P=0.001) ; 61.1 \% \\
\text { improved } 2 \text { lines or more }\end{array}$ & $\begin{array}{l}\text { Mean CMT decreased from } \\
344.9 \mu \mathrm{m} \text { to } 212.6 \mu \mathrm{m}(P=0.015)\end{array}$ \\
\hline $\begin{array}{l}\text { Silva } \\
\text { et } \mathrm{al}^{21}\end{array}$ & $\begin{array}{l}\text { Retrospective, multicenter, } \\
\text { consecutive, nonrandomized, } \\
\text { interventional case series, } 26 \text { eyes, } \\
\text { follow-up } 6 \text { months }\end{array}$ & Not stated & $\begin{array}{l}\text { VA improved from } 20 / 100 \text { to } \\
20 / 50(P=0.01) ; 31 \% \text { improved } \\
\geq 3 \text { lines (at one month) }\end{array}$ & Significant reduction CMT \\
\hline $\begin{array}{l}\text { Current } \\
\text { report }\end{array}$ & $\begin{array}{l}\text { Case report, I eye, follow-up } \\
12 \text { months }\end{array}$ & I & Improved from $6 / 30$ to $6 / 6$ & Not performed \\
\hline
\end{tabular}

Abbreviations: BCVA, best corrected visual acuity; CMT, central macular thickness; VA, visual acuity; OCT, optical coherence tomography. 
macular degeneration, and thus a possible higher penetration ability of the small ranibizumab molecule might be a significant advantage. $^{11}$

Table 1 summarizes seven reported studies and one case report of intravitreal ranibizumab for myopic $\mathrm{CNV}$ in the literature from 2008 to $2011 .^{11,15-21}$ Based on these studies, intravitreal ranibizumab appears to be effective for the treatment of myopic CNV, resulting in functional and anatomic improvements. A study done by Lai et $\mathrm{al}^{19}$ and a case report by Kumaran et $\mathrm{a}^{18}$ showed that a single injection of intravitreal ranibizumab is effective for the treatment of myopic choroidal neovascularization as was presented in this patient. The number of intravitreal ranibizumab injections required depends on patient characteristics, including location of myopic $\mathrm{CNV}$ and prior treatment. ${ }^{15}$ In conclusion, a single injection of ranibizumab showed improvement in this patient with myopic $\mathrm{CNV}$.

\section{Disclosure}

The authors report no conflicts of interest in this work.

\section{References}

1. Blinder KJ, Blumenkranz MS, Bressler NM, et al. Verteporfin therapy of subfoveal choroidal neovascularization in pathologic myopia: 2-year results of a randomized clinical trial-VIP report no. 3. Ophthalmology. 2003;110:667-673.

2. Soubrane G. Choroidal neovascularisation in pathologic myopia: recent developments in diagnosis and treatment. Surv Opthalmol. 2008;53:121-138.

3. Secretan M, Kuhn D, Soubrane G, Coscas G. Long term visual outcome of choroidal neovascularisation in pathologic myopia: natural history and laser treatment. Eur J Ophthalmol. 1997;7:307-316.

4. Hamelin N, Glacet-Bernard A, Brindeau C, Mimoun G, Coscas G, Soubrane G. Surgical treatment of subfoveal neovascularisation in myopia: macular translocation vs surgical removal. Am J Ophthalmol. 2002;133:530-536.

5. Ruiz-Moreno JM, de la Vega C. Surgical removal of subfoveal choroidal neovascularisation in highly myopic patients. $\mathrm{Br} J$ Ophthalmol. 2001;85:1041-1043.

6. Mateo C, Moreno J, Rosales G, et al. Two-year results of macular translocation with sclera infolding in myopic choroidal neovascularisation. Semin Ophthalmol. 2004;19:29-42.
7. Montero JA, Ruiz-Moreno JM. Combined photodynamic therapy and intravitreal triamcinolone injection for the treatment of choroidal neovascularisation secondary to pathological myopia: a pilot study. $\mathrm{Br}$ J Ophthalmol. 2007;91:131-133.

8. Chan WM, Lai TYY, Liu DTL, Lam DSC. Intravitreal bevacizumab (Avastin) for myopia choroidal neovascularisation: six-month results of a prospective pilot study. Ophthalmology. 2007;114:2190-2196.

9. Nguyen QD, Shah S, Tatlipinar S, Do DV, Anden EV, Campochiaro PA. Bevacizumab suppresses choroidal neovascularisation caused by pathological myopia. Br J Ophthalmol. 2005;89:1368-1370.

10. Yamamoto I, Rogers AH, Reichel E, Yates PA, Duker JS. Intravitreal bevacizumab (Avastin) as treatment for subfoveal choroidal neovascularisation secondary to pathological myopia. Br J Ophthalmol. 2007;91:157-160.

11. Konstantinidis L, Mantel I, Pournaras JAC, Zografos L, Ambresin A. Intravitreal ranibizumab (Lucentis ${ }^{\circledR}$ ) for the treatment of myopic choroidal neovascularisation. Graefes Arch Clin Exp Ophthalmol. 2009;247:311-318.

12. Ikuno Y, Sayanagi K, Soga K, et al. Intravitreal bevacizumab for choroidal neovascularisation attributable to pathological myopia: one year results. Am J Ophthalmol. 2009;147:94-100.

13. Voykov B, Gelisken F, Inhoffen W, Voelker M, Bartz-Schmidt KU, Ziemssen F. Bevacizumab for choroidal neovascularisation secondary to pathologic myopia: is there a decline of the treatment efficacy after 2 years? Graefes Arch Clin Exp Ophthalmol. 2010;248:543-550.

14. Rosenfeld PJ, Brown DM, Heier JS, et al. Ranibizumab for neovascular age-related macular degeneration. $N$ Engl J Med. 2006;355: 1419-1431.

15. Calvo-Gonzalez C, Reche-Frutos J, Donate J, Fernandez-Perez C, Garcia-Feijoo J. Intravitreal ranibizumab for myopic choroidal neovascularization: factors predictive of visual outcome and need for retreatment. Am J Ophthalmol. 2011;151:529-554.

16. Silva RM, Ruiz-Moreno JM, Rosa P, et al. Intravitreal ranibizumab for myopic choroidal neovascularization: 12-month results. Retina. 2010; 30:407-412.

17. Mones JM, Amselem L, Serrano A, Garcia M, Hijano M. Intravitreal ranibizumab for choroidal neovascularization secondary to pathologic myopia: 12-month results. Eye. 2009;23:1275-1280.

18. Kumaran N, Sim DA, Tufail A. Long-term remission of myopic choroidal neovascular membrane after treatment with ranibizumab: A case report. J Med Case Reports. 2009;3:84.

19. Lai TY, Chan WM, Liu DT, Lam DS. Intravitreal ranibizumab for the primary treatment of choroidal neovascularization secondary to pathologic myopia. Retina. 2009;29:750-756.

20. Torron C, Egea C, Ferrer E, Ruiz O, Honrubia FM. Ranibizumab as treatment for myopic choroidal neovascularization. Arch Soc Esp Oftalmol. 2009;84:507-514. Spanish.

21. Silva RM, Ruiz-Moreno JM, Nascimento J, et al. Short-term efficacy and safety of intravitreal ranibizumab for myopic choroidal neovascularization. Retina. 2008;28:1117-1123.
Clinical Ophthalmology

\section{Publish your work in this journal}

Clinical Ophthalmology is an international, peer-reviewed journal covering all subspecialties within ophthalmology. Key topics include: Optometry; Visual science; Pharmacology and drug therapy in eye diseases; Basic Sciences; Primary and Secondary eye care; Patient Safety and Quality of Care Improvements. This journal is indexed on Submit your manuscript here: http://www.dovepress.com/clinical-ophthalmology-journal

\section{Dovepress}

PubMed Central and CAS, and is the official journal of The Society of Clinical Ophthalmology (SCO). The manuscript management system is completely online and includes a very quick and fair peer-review system, which is all easy to use. Visit http://www.dovepress.com/ testimonials.php to read real quotes from published authors. 